\title{
Functional cosmetic properties and antimicrobial activity of extracts from Saururus chinensis by elicitor treatment
}

\author{
Eun-Ho Lee $^{1} \cdot$ Byung-Oh Kim $^{1} \cdot$ In-Kyu Kang ${ }^{2} \cdot$ Hee-Young Jung ${ }^{3} \cdot$ Young-Je Cho $^{1}$ \\ Elicitor 처리에 의한 삼백초 추출물(Saururus chinensis)의 \\ 미용식품활성 및 피부상재균 억제효과
}

이은호 ${ }^{1} \cdot$ 김병오 $^{1} \cdot$ 강인규 $^{2} \cdot$ 정희영 $^{3} \cdot$ 조영제 $^{1}$

Received: 20 April 2018 / Accepted: 23 May 2018 / Published Online: 30 June 2018

(C) The Korean Society for Applied Biological Chemistry 2018

\begin{abstract}
In this study, the functional cosmetic activity of water and ethanol extracts from Saururus chinensis by elicitor treatment are examined. Anti-oxidative activity 1,1-diphenyl-2-picrylhydrazyl and antioxidant protection factor of elicitor treated $S$. chinensis extract increased in concentration dependent manner as concentration increased from $1.5 \mathrm{mg}$ elicitor/leaf $1 \mathrm{~g}$ (group A) to $3.0 \mathrm{mg}$ elicitor/ leaf $1 \mathrm{~g}$ (group B). Also, 70\% ethanol extract showed higher antioxidative activity than water extract. Elicitor treated $S$. chinensis extract showed similar inhibitory effect on elastase activity and whitening effect indicating low effect of elicitor on elastase inhibition and whitening effect. However, it showed high antiinflammatory and anti-microbial activity compared to control group. Both group A and B showed high anti-inflammatory and anti-microbial activity then control group indicating that elicitor
\end{abstract}

Young-Je Cho $(\square)$

E-mail: yjcho@knu.ac.kr

${ }^{1}$ School of Food science \& Biotechnology/Food \& Bio-Industry Research Institute, Kyungpook National University, 80 Daehakro, Bukgu, Daegu 41566, Republic of Korea

${ }^{2}$ Department of Horticultural Science, Kyungpook National University, 80 Daehakro, Bukgu, Daegu 41566, Republic of Korea

${ }^{3}$ School of Applied Biosciences, Kyungpook National University, 80 Daehakro, Bukgu, Daegu 41566, Republic of Korea

This is an Open Access article distributed under the terms of the Creative Commons Attribution Non-Commercial License (http://creativecommons. org/licenses/by-nc/3.0/) which permits unrestricted non-commercial use, distribution, and reproduction in any medium, provided the original work is properly cited. treatment is suitable for biomass method used for industrializing useful compounds. Therefore, elicitor treatment during $S$. chinensis cultivation will increase bioactivity in the plant source which will yield high quality for industrialization.

Keywords Anti-microbial activity · Elicitor · Extract · Healthy beauty foods $\cdot$ Saururus chinensis

\section{서 론}

인간의 피부는 노화되어감에 따라 기능적, 구조적으로 변화되어 시각적으로 나타나게 되는데, 호르몬의 분비가 감소하고, 면역 세포의 기능이 저하되어 피부가 얇아져 피부탄력 감소로 인한 주름 생성, 피지생성 감소로 인한 건성 피부화, 경피 수분 손실 증가뿐만 아니라 멜라닌 생성에 의한 얼굴의 명도가 낮아지고 기미와 검버섯 등이 생성되는 등 여러 가지 현상이 나타나게 된다[1,2]. 또한 피부는 항상 산소와 접촉하고 있고 자외선에 쉽 게 노출되어 활성 산소 등에 의한 피부의 광산화적 손상과 광 노화가 발생할 위험이 항상 존재한다. 피부가 자외선을 받게 되 면 피부표면에 존재하는 지질이 노출된 피부표면에서 지질과산 화물로 변화하여 산화하게 된다. 피부의 지질은 상피세포 증식 조절, 세포 간 응집, 표피세포의 탈락에 관여하며 $[3,4,5,6]$, 자외 선 노출은 피부의 마지막 barrier인 각질층의 지질을 산화시켜 피부장벽의 손상을 초래함으로써 피부의 수분유지와 외부수분 의 유입을 막는 기능을 저하 시킨다[7,8].

현재 인류의 당면과제인 노화 억제를 위한 연구의 일환으로 피부노화 억제 및 개선을 위해 많은 연구가 진행되고 있으며 
노화억제를 위한 기능성 물질들의 개발이 진행되고 있다 $[9,10]$ 이러한 기능성 물질에 대한 연구는 인체에 부작용이 작은 천연 물에 대한 관심으로 집중되고 있으며, 동양의학에서 오랜 기간 치료와 예방의 목적으로 사용되어온 한약재와 약용식물들과 식 물의 2 차 대사산물이 가지는 생체에 대한 생리활성 물질 등 인 체에 대한 안전성이 비교적 검증된 것을 이용하는 연구가 시도 되었다[11,12,13]. 따라서 피부 구성물질을 증가시키거나, 멜라 닌 생합성을 억제하는 물질 등을 적용시키는 것은 노화로 인해 발생하게 되는 주름개선, 탄력복원 및 미백효과 등의 피부개선 효과를 볼 수 있는 것으로 알려져 있다 $[14,15,16]$.

삼백초(Saururus chinensis)는 예로부터 다양한 피부질환에 잎 을 달여 마시거나 즙을 내어 마시거나 병변에 도포하는 방법으 로 피부질환 및 내과적 질환에 전통적인 민간요법으로 사용 되 어 왔다[17].

본 연구는 기존의 농지에서 재배되고 있는 약용 식물에 elicitation 기법을 접목하여 삼백초의 이차대사산물의 생산성을 증대시키고 화장품기능성을 증대시키는 것을 목적으로 하는 것 으로써, 삼백초의 유용성분 생산성을 높이기 위한 elicitation 기 법을 노지재배에 적용하기 위한 적절한 elicitation system을 확 립하는 시스템을 갖추는 것을 목적으로 하였다.

\section{실험 재료 및 방법}

\section{Elicitor의 제조 및 적용}

본 실험에서 사용된 elicitor는 Cho 등의 방법[18]에 따라 이스 트 추출물 수용액에 단백질 분해효소(Aspergillus fumigatus 배 양액에서 분리한 단백질 분해효소)를 처리하고, ethanol을 첨가 로 유도된 불용성 성분인 침전물을 회수하고 건조하여 이스트 효소 분해물을 제조하였다. 제조된 이스트 효소 분해물 분말 $\mathrm{kg}$ 당 $5 \mathrm{~g}$ 의 $\mathrm{CuCl}_{2}$ 를 균질하게 혼합하여 elicitor 분말을 제조하여 삼백초의 어린잎이 자라기 시작하는 4 월 하순경(4월 30일)부터 잎이 다 자라는 5 월 중순경(5월 14일)까지 생잎 $\mathrm{g}$ 당 $1.5 \mathrm{mg}$ (group A)과 $3 \mathrm{mg}$ (group B)의 농도로 3회에 걸쳐 용액으로 제조하여 분무기를 사용하여 직접 잎에 분무하였다.

\section{추출물의 제조}

삼백초 잎을 수확하여 $45^{\circ} \mathrm{C}$ 에서 건조시킨 후 $40 \mathrm{mesh}$ 로 분쇄 하여 시료로 사용하였다. 물 추출물의 경우 시료 $1 \mathrm{~g}$ 에 증류수 $200 \mathrm{~mL}$ 을 넣고 액이 $100 \mathrm{~mL}$ 이 될 때까지 가열한 후 냉각하였 으며, ethanol 추출물은 시료에 $100 \mathrm{~mL}$ 의 $70 \%$ ethanol을 가하 고 homogenizer로 $20,000 \mathrm{rpm}$ 에서 1 분간 균질화 시킨 후 12 시 간동안 교반 추출하였다. 물과 ethanol 추출액은 whatman No.1 filter paper로 여과한 후 ethanol 추출물은 rotary vacuum evaporator (BUCHI R-200, Flawil, Switzerland)를 사용하여 추 출에 사용한 ethanol을 모두 휘발시킨 후 total volume을 DW 로 조절하였으며, 필요에 따라 추출물 모두 농축하여 농도(50$200 \mu \mathrm{g} / \mathrm{g}$ )를 조절한 후 시료로 사용하였다.

\section{Total phenolic 정량}

Total phenolic 정량은 추출물 $1 \mathrm{~mL}$ 에 $95 \%$ ethanol $1 \mathrm{~mL}$ 와 증 류수 $5 \mathrm{~mL}$ 를 첨가하고 $1 \mathrm{~N}$ Folin-ciocalteu reagent $0.5 \mathrm{~mL}$ 를
잘 섞어 5 분간 방치한 후 $\mathrm{Na}_{2} \mathrm{CO}_{3} 1 \mathrm{~mL}$ 를 가하여 흡광도 725 $\mathrm{nm}$ 에서 1 시간 이내에 측정하여 gallic acid를 이용한 표준곡선 (Total phenolic compounds content in gallic acid (10-200 $\mu \mathrm{g} / \mathrm{mL}$ ) was calculated using the following equation based on the calibration curve: $y=0.0083 x-0.027, R^{2}=0.9963$, where $\mathrm{y}$ was the absorbance, and $\mathrm{x}$ was the gallic acid equivalent $(\mu \mathrm{g} / \mathrm{mL}))$ 으로부터 양을 환산하였다[9].

\section{항산화 효과 측정}

1,1-diphenyl-2-picrylhydrazyl (DPPH) radical에 대한 소거활성 은 Lee 등의 방법[9]에 준하여 측정하였으며, 전자공여능 $(\%)$ 은 1 -(반응구의 흡광도/대조구의 흡광도) $\times 100$ 으로 나타내었다. Antioxidant protection factor (PF)는 Andarwulan과 Shetty의 방법[19]에 준하여 측정하였으며, $\mathrm{PF}$ 는 반응구의 흡광도/대조구 의 비로 나타내었다.

\section{미백효과(Tyrosinase 억제) 측정}

Tyrosinase 저해효과 측정은 Vincent와 Hearing의 방법[20]에 준 하여 측정하였다. 반응구는 $0.1 \mathrm{M}$ sodium phosphate buffer (pH 6.8) $2.3 \mathrm{~mL}$ 와 기질액 $1.5 \mathrm{mM}$ L-tyrosine 용액 $0.4 \mathrm{~mL}$ 의 혼합액에 mushroom tyrosinase (Sigma-Aldrich Co, Louis, MO, USA, $250 \mathrm{U} / \mathrm{mL}) 0.1 \mathrm{~mL}$ 와 시료 $0.2 \mathrm{~mL}$ 를 넣고 대조구 에는 시료 대신 증류수를 $0.2 \mathrm{~mL}$ 를 첨가하여 $37^{\circ} \mathrm{C}$ 에서 20 분간 반응시켜 흡광도 $475 \mathrm{~nm}$ 에서 측정하여, 저해율 $(\%)$ 은 (1-시료의 absorbance/대조구의 absorbance) $\times 100$ 으로 계산하였다.

\section{수렴효과(astringent) 측정}

Astringent 활성 측정은 Wunsch과 Heidrich의 방법[21]에 따라 측정하였다. 피부 단백질과 유사한 혈액 단백질(hemoglobin)을 사용하여, 원심분리관 용기에 각각의 시료용액과 헤모글로빈 용 액을 $1: 1$ 로 넣어서 진탕 혼합한 다음 $1,500 \mathrm{rpm}$ 에서 3 분간 원 심분리 후 $576 \mathrm{~nm}$ 에서 흡광도를 측정하였다. Astringent 활성 $(\%)$ 은 $(1-$ 시료의 흡광도/대조구의 흡광도 $) \times 100$ 으로 계산하였다.

\section{주름개선 효과(elastase 저해) 측정}

Elastase 저해효과 측정은 Kraunsoe 등의 방법[22]에 준하여 측 정하였다. 반응구는 $0.2 \mathrm{M}$ Tris- $\mathrm{HCl}$ buffer $(\mathrm{pH} 8.0) 1 \mathrm{~mL}$ 에 기질액 $0.8 \mathrm{mM} \mathrm{N}$-succinyl-(Ala) ${ }^{3}-\gamma$-nitroanilide 용액 $0.1 \mathrm{~mL}$ 의 혼합액에 $1.0 \mathrm{U} / \mathrm{mL}$ porcine pancreatice elastase (PPE) (SigmaAldrich Co.) 효소용액 $0.1 \mathrm{~mL}$ 와 시료 $0.1 \mathrm{~mL}$ 를 넣고 대조구에 는 시료 대신 증류수 $0.1 \mathrm{~mL}$ 를 첨가하여 $37^{\circ} \mathrm{C}$ 에서 20 분간 반 응시켜 $\gamma$-nitroaniline 생성량을 흡광도 $410 \mathrm{~nm}$ 에서 측정하였다. 저해율 $(\%)$ 은 (1-시료의 absorbance/대조구의 absorbance $) \times 100$ 으 로 계산하였다.

\section{염중억제 작용(Hyaluronidase, HAase 억제) 측정}

HAase 저해효과는 Lee 등의 방법[9]에 준하여 측정하였다. 반 응구는 시료 $0.5 \mathrm{~mL}$ 에 $20 \mathrm{mM}$ Sodium phosphate buffer $(\mathrm{pH}$ 6.9)에 녹인 HAase $(1,000 \mathrm{U} / \mathrm{mL}) \quad 0.5 \mathrm{~mL}$ 을 혼합하여 $38^{\circ} \mathrm{C}$ 에 서 5 분간 반응시키고 $0.3 \mathrm{M}$ phosphate buffer (pH 5.3)에 녹인 기질 $(4 \mathrm{mg} / \mathrm{mL}) \quad 0.5 \mathrm{~mL}$ 을 넣어 다시 $38^{\circ} \mathrm{C}$ 에서 45 분간 반응시 킨 후 $0.04 \mathrm{M}$ acetate buffer $(\mathrm{pH} 3.75)$ 에 녹인 알부민용액 5 
$\mathrm{mL}$ 을 첨가한 후 5 분간 방치하고 $600 \mathrm{~nm}$ 에서 투과율을 측정하 였다. 대조구는 시료 대신 증류수 $0.5 \mathrm{~mL}$ 를 넣어 반응시켰다. 저해율 $(\%)$ 은 (1-시료의 투과율/대조구의 투과율 $) \times 100$ 으로 계산 하였다.

\section{피부상재균에 대한 항균활성 검색}

실험에 사용한 균주는 피부상재균으로써 여드름의 발생에 관여 하는 Propionebacterium acnes와 세균각막염, 안검결막염 등의 원인균인 Staphylococcus epidermidis 표준균주인 KCTC 1917 와 Candida albicans 표준균주인 KCTC 7965와 피부상재균으 로써 피부표면에서 쉽게 발견되고, 공기 및 토양 등의 자연계 에 광범위하게 분포하고 있어 식품에 쉽게 오염되기 때문에 식 중독의 원인균이 되기도 하는 Staphylococcus aureus 표준균주 인 KCTC 1039 및 병원성 대장균인 Escherichia coli 표준균주 KCTC 1039 를 사용하였다. 균주의 배양은 S. epidermidis의 배 양에는 Nutrient Medium을 사용하였고, C. albicans의 배양에는 YM Medium을, S. aureus 및 E. coli의 배양에는 Nutrient Medium을 사용하여 배양은 agar plate상으로 37 의 BOD incubator에서 24-48시간 동안 실시하였다[23].

항균력 측정은 paper disc법을 이용하여 생육 저해환(Clear zone)을 측정하였다. 즉, 평판배지에 배양된 각 균주를 1 백금 이 취해서 액체배지 $10 \mathrm{~mL}$ 에서 18-24시간 배양하여 활성화시킨 후 다시 액체배지 $10 \mathrm{~mL}$ 에 균액을 $0.1 \mathrm{~mL}$ 접종하여 36시간 본 배양한 후 평판배지 1 개당 균수가 약 $1 \times 10^{7}$ cells되게 접종하여 멸균 면봉으로 균일하게 도말하였다. Disc method에 의한 항균 활성 검색은 최적배지 agar plate에 준비한 균 배양액 $100 \mu \mathrm{L}$ 를 분주하여 멸균 유리봉으로 도말한 다음, 멸균된 지름 $8 \mathrm{~mm}$ 크 기의 disc paper를 올려놓고 $0.45 \mu \mathrm{m}$ membrane filter로 제균한 시료용액 $100 \mu \mathrm{L}$ 에 phenolics 농도가 50, 100, 150 및 $200 \mu \mathrm{g} /$ $100 \mu \mathrm{L}$ 가 되도록 각각 분주하였다. 대조구로는 멸균수 $100 \mu \mathrm{L}$ 를 흡수시켜 24시간 동안 배양하여, disc 주위의 clear zone 생성 유무와 직경을 측정함으로써 항균활성을 계산하였다[24].

\section{통계처리}

모든 실험은 6 회 이상 반복 측정하였고 자료의 통계처리는 SPSS 23 for windows (Statistical Package for Social Science, SPSS Inc., Chicago, IL, USA)를 이용하여 평균표준편차 (mean \pm standard deviation)로 표시하였고 분산분석 Duncan's multiple range test, one-way ANOVA를 실시하여 시료 간의 유의차를 $p<0.05$ 수준으로 비교 분석하였다.

\section{결과 및 고찰}

\section{Elicitor 처리에 의한 삼백초 추출물의 항산화 효과 변화}

Elicitor 처리한 삼백초와 비처리 삼백초 추출물의 oxidative free radical 반응을 이용한 환원성 물질의 분석인 $\mathrm{DPPH}$ 법으로 비교 측정한 결과, Figs. 1A-C에서와 같이 elicitor 처리한 삼백초 추 출물의 $\mathrm{DPPH}$ 소거능이 비처리군에 비해 우수한 항산화 효과 를 나타내었으며, $1.5 \mathrm{mg}$ elicitor/leaf $1 \mathrm{~g}$ (group A)에서 3.0 $\mathrm{mg}$ elicitor/leaf $1 \mathrm{~g}$ (group B)으로 처리 농도가 높아질수록 항 산화 효과는 높아지는 것으로 확인되었으며, elicitor 처리에 의
해 물 추출물보다 $70 \%$ ethanol 추출물의 항산화 효과가 더 우 수한 효능을 나타내었다. 지용성 비타민 $\mathrm{A}$ 인 $\beta$-carotene이 가지 고 있는 황색을 이용하여 황색의 변화 정도에 따른 지용성 물 질에 대한 항산화력을 측정하는 실험법인 $\mathrm{PF}$ 를 측정한 결과 elicitor 처리한 삼백초 추출물의 경우 Figs. 1D-F에서와 같이 group $\mathrm{A}$ 에서는 ethanol 추출물에서 대조구인 비처리군에 비해 상대적으로 높은 지용성 물질에 대한 항산화력의 증대가 관찰 되었고, group $\mathrm{B}$ 에서는 물 추출물에서 대조구와 group $\mathrm{A}$ 를 능 가하는 우수한 항산화력이 확인되었으며, elicitor 처리군의 경우 positive control로 사용한 합성항산화제인 BHA보다 우수한 효 능을 나타내어 천연항산화제로서의 개발 가치와 가능성을 보여 주었다. 또한 위의 결과와 같이 elicitor 처리 농도별에 따른 효 능의 차이는 삼백초의 성장과정에서 방어기작으로 만들어지는 phenolic compounds의 profile 차이에 의한 것으로 추정이 되었 으며, 향후 이에 대한 후속연구도 병행이 되어야 할 것으로 판 단되었다.

\section{Elicitor 처리한 삼백초 추출물의 미백 효과}

사람의 피부색은 멜라닌(melanin)이나 카로틴(carotene)과 같은 색소 성분과 혈관의 분포, 각질층의 두께 등에 의해서 결정되 는데, 이는 멜라닌이 피부색을 결정하는 가장 중요한 요소로 자 외선을 차단하는 기능도 갖고 있지만 국소적으로 과도하게 합 성되거나, 멜라닌 생성에 이상이 생기면 melasma, freckle 및 hyperpigmentation을 유발하게 된다. 따라서 멜라닌 합성의 기질 인 tyrosine을 분해하는 tyrosinase를 저해함으로써 멜라닌의 합 성을 억제하여 피부의 미백효과를 볼 수 있다. Elicitor 처리한 삼백초 추출물의 tyrosinase 억제 효과는 Figs. 2A-C에서와 같 이 비처리군인 대조구와 유사한 효소 억제 효과를 나타내어 elicitor 처리가 삼백초 추출물의 미백효과 증대에는 영향을 미 치지 않는 것으로 확인되었다.

\section{Elicitor 처리한 삼백초 추출물의 수렴 효과}

수렴작용의 원리는 피부 단백질이 tannic acid, epigallocatechin gallate와 같은 phytochemical compound 또는 phenolic compound 와 결합하여 가교결합을 형성하여 피부가 수축되는 현상을 말 한다. 수렴이란 뜻에는 기본적으로 주름이 지고 혹은 움츠린다 는 의미가 있다. 수렴제는 식품에서는 혀 점막에 작용하여 떫 은맛을 느끼게 하는 작용을 나타내므로 불호성분의 대명사라 할 수 있다. 그러나 피부에 작용 시 피부와 점막 혈관 등을 수축 시키는 작용이 있고, 세포간극 및 림프간극을 가로막아 점액의 분비를 억제시키는 효과가 있으며, 모공을 축소하여 피부를 조 이게 만들어 피부가 팽팽하게 느끼게 하는 작용을 하고, 모공 축소로 인하여 모발의 이탈을 방지하는 효과도 있다. 이러한 수 렴제는 단백질과 결합하는 성질을 가지기 때문에 일반적으로 헤 모글로빈 단백질이 추출물과 결합하는 정도에 따라서 수렴성 효 과 정도를 측정할 수 있다. Wunsch과 Heidrich[21]은 이러한 수렴작용에는 외용 혹은 내용에 의해서 피부와 점막의 표면에 난용성의 피박을 형성하고 그 결과 구조를 보호하거나, 혹은 조 직을 조밀하게 하여 세포막의 투과성을 감소시키는 효과가 있 다고 하였다. Elicitor 처리한 삼백초 추출물의 수렴효과는 Figs. $3 \mathrm{~A}-\mathrm{C}$ 에서와 같이 비처리군인 대조구에 비하여 오히려 수렴효과 가 낮아지는 현상을 나타내어 삼백초를 식품에 적용시킬 때에 

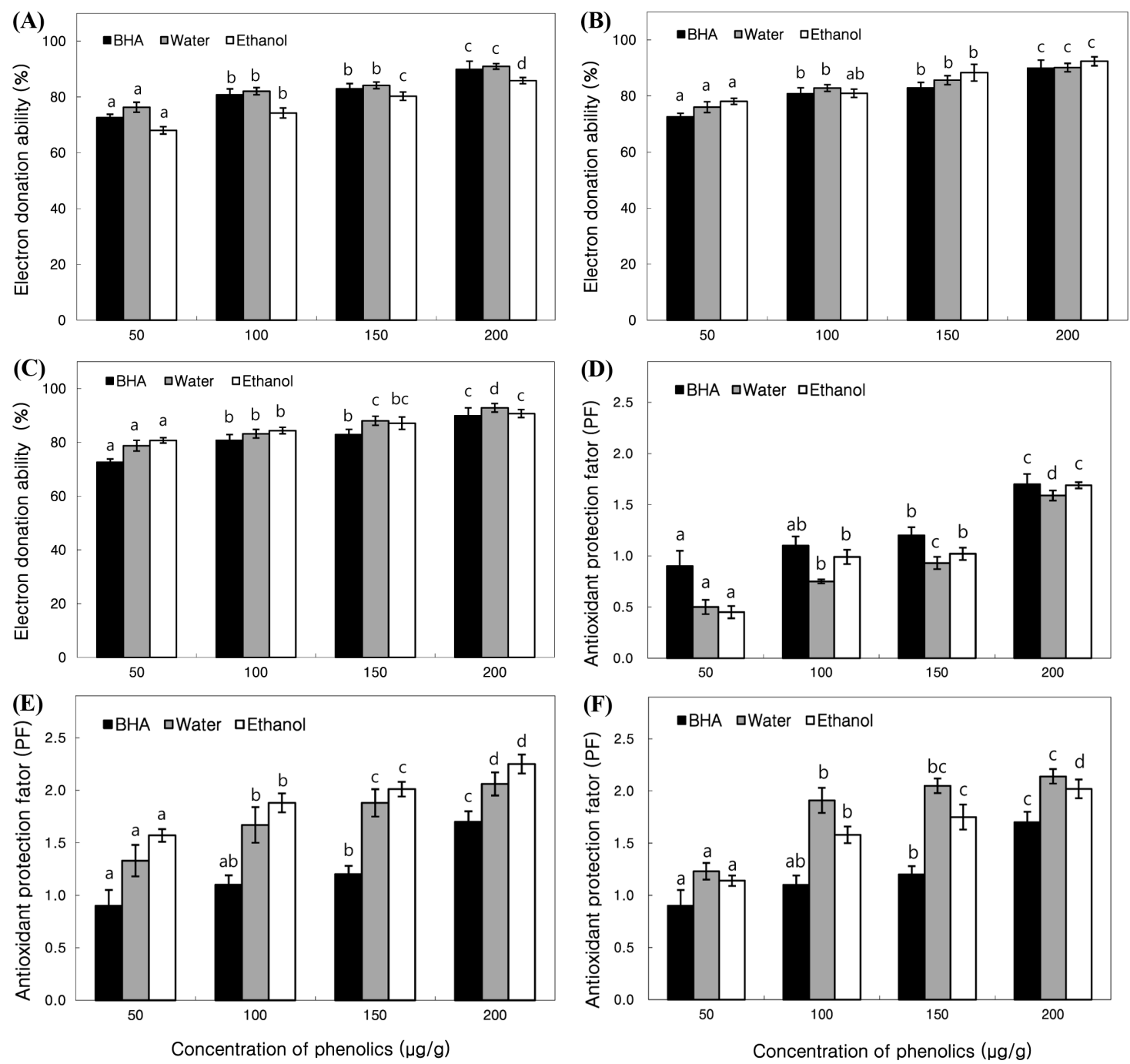

Fig. 1 Inhibition of DPPH (A), (B), (C) and PF (D), (E), (F) of extracts from S. chinensis by elicitor treatment. (A) and (D): Control, (B) and (E): group A, (C) and (F): group B. Control: non hydrolyzed yeast extracts treatment, group A: 1.5 mg hydrolyzed yeast extracts/leaf g treatment, group B: 3.0 mg hydrolyzed yeast extracts/leaf $\mathrm{g}$ treatment. Means with different letters (a-d) above the bars are significantly different at $p<0.05$ by a Duncan's multiple range tests

는 떫은맛을 덜 느끼게 하는 positive의 효과를 나타낼 수 있을 것이라 판단되었으며, 미용기능성을 고려한다면 모공축소 효과 등은 기대할 수 없을 것으로 판단되었다.

Elicitor 처리한 삼백초 추출물의 주름개선(elastase 억제) 효과 인체의 중성구 과립구내에 존재하는 elastase는 진피 내 피부탄 력을 유지하는데 주요한 기질 단백질인 엘라스틴을 분해하는 효 소이며, 다른 중요한 기질 단백질인 콜라겐을 분해할 수 있는 비특이적 가수분해 효소이다. 따라서 elastase 저해제는 피부 주 름개선을 하는 작용을 나타내며, ursolic acid 등이 elastase 저 해제로 이용되고 있다. 또한 Giacomoni과 Rein[25]과 Cannell 등[26]은 체내의 엘라스틴을 분해하는 백혈구 과립 효소 중의 하나로 이상조직에서는 그 효소의 활성이 극히 높아 조직 파괴 에 직접적인 원인이 되어 피부주름 및 탄력성 소실을 유발한다 고 하였다. 따라서 elastase 저해활성을 측정함으로써 주름개선
의 효과와 상관 있음을 알 수 있다. Elicitor 처리한 삼백초 추 출물의 elastase 억제 효과는 Figs. $4 \mathrm{~A}-\mathrm{C}$ 에서와 같이 비처리군 인 대조구보다 우수한 효소 억제 효과를 나타내었으며, group $\mathrm{B}$ 의 경우에는 물과 ethanol 추출물 모두 효능의 증가를 나타내 어 elicitor 처리한 삼백초 추출물이 주름개선 효과의 증대에 영 향을 미치는 것으로 확인되었다. 또한 positive control로 사용한 ursolic acid보다 elicitor 비처리군, 처리군 모두 우수한 효능을 나타내어 삼백초 소재와 elicitor 처리의 우수성을 확인할 수 있 었으며, 주름개선에 영향을 미치는 기능성 소재로서의 개발 가 능성이 있다고 판단되었다.

\section{Elicitor 처리한 삼백초 추출물의 염증 억제 효과}

히아루론산(hyaluronic acid, HA)은 고분자 다당으로 진피층의 섬유아세포에서 산출되어, 표피, 진피에 주요한 세포외 매트릭 스로 glucuronic acid와 glucosamine이 반복해서 연결된 점액성 

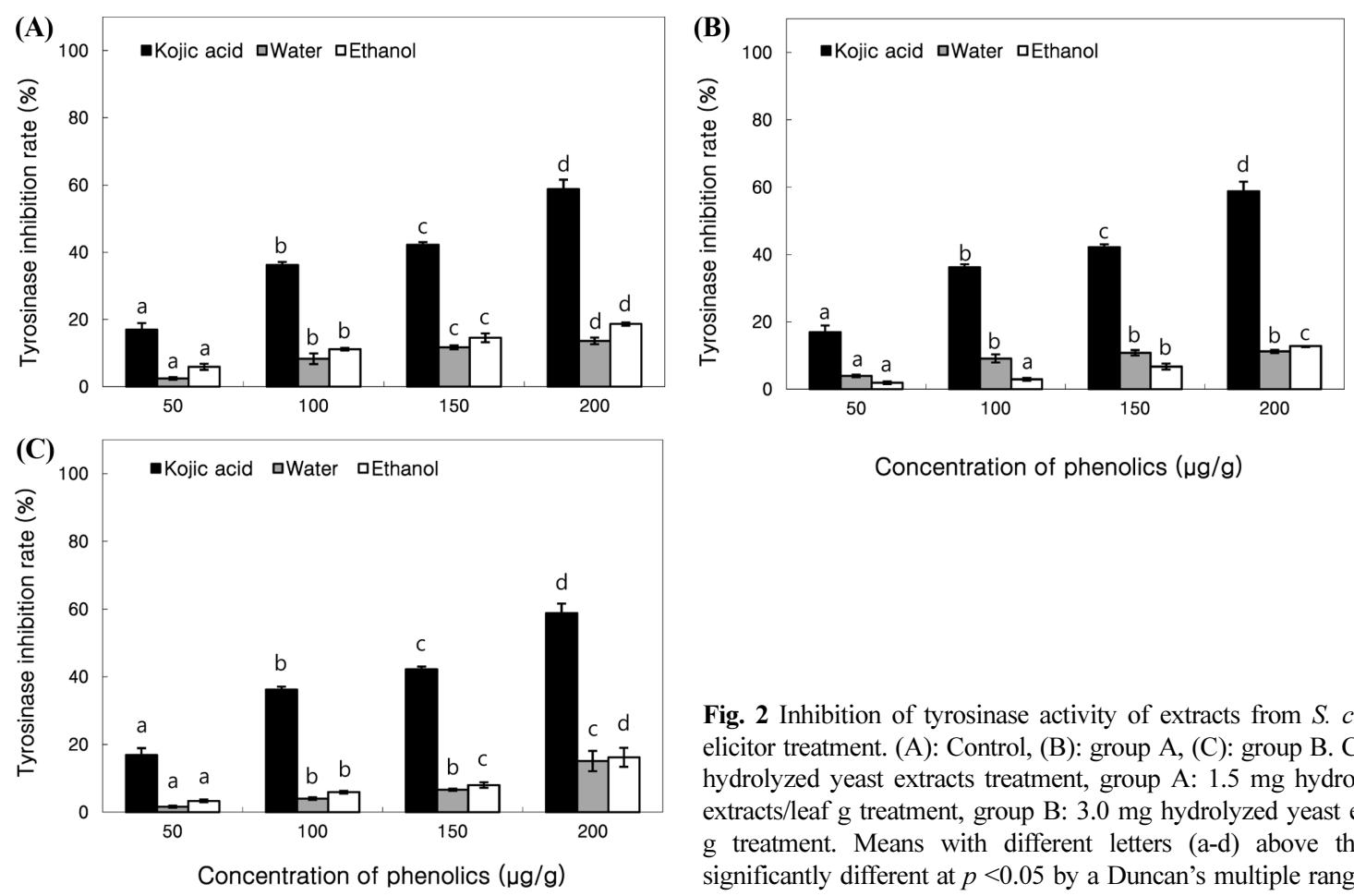

Concentration of phenolics $(\mu \mathrm{g} / \mathrm{g})$

Fig. 2 Inhibition of tyrosinase activity of extracts from $S$. chinensis by elicitor treatment. (A): Control, (B): group A, (C): group B. Control: non hydrolyzed yeast extracts treatment, group $\mathrm{A}: 1.5 \mathrm{mg}$ hydrolyzed yeast extracts/leaf g treatment, group B: $3.0 \mathrm{mg}$ hydrolyzed yeast extracts/leaf $\mathrm{g}$ treatment. Means with different letters (a-d) above the bars are significantly different at $p<0.05$ by a Duncan's multiple range tests
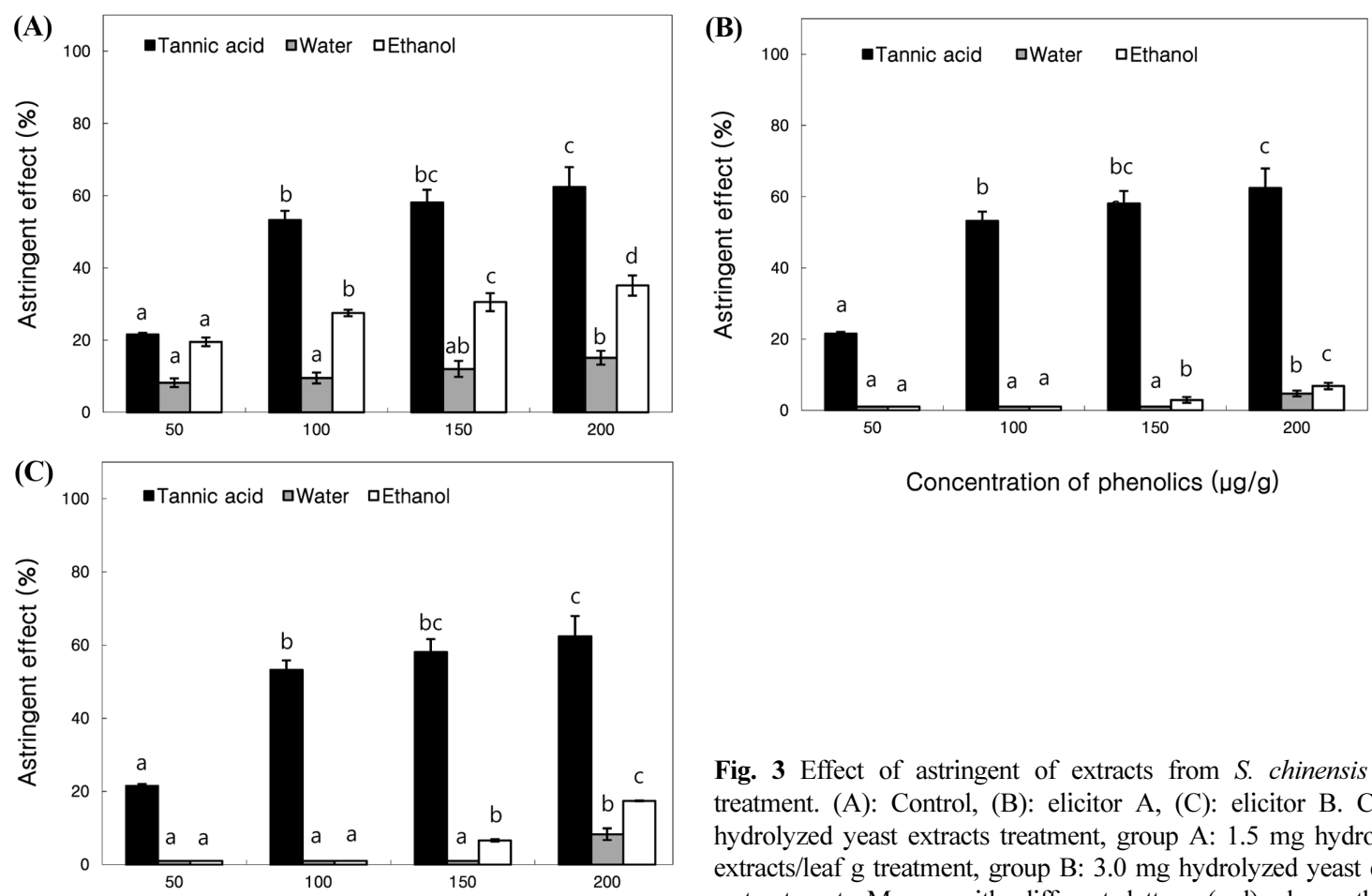

Concentration of phenolics $(\mu \mathrm{g} / \mathrm{g})$

moucopolysaccharide이다. 그리고, 염증 형성의 중요 요소인 macrophage의 phagocytic ability를 저해하는 한편, HA 분해 산물 혹은 저분자 $\mathrm{HA}$ 는 상처 치유과정에서 inflammation, fibrosism, collagen deposition을 증가시키는 것으로 고분자 $\mathrm{HA}$ 의 분해효 소인 HAase의 저해에 의해 $\mathrm{HA}$ 의 고분자 형태를 유지하게 함

Fig. 3 Effect of astringent of extracts from $S$. chinensis by elicitor treatment. (A): Control, (B): elicitor A, (C): elicitor B. Control: non hydrolyzed yeast extracts treatment, group $\mathrm{A}: 1.5 \mathrm{mg}$ hydrolyzed yeast extracts/leaf g treatment, group B: $3.0 \mathrm{mg}$ hydrolyzed yeast extracts/leaf $\mathrm{g}$ treatment. Means with different letters (a-d) above the bars are significantly different at $p<0.05$ by a Duncan's multiple range tests

으로써 항염증 효과를 기대할 수 있다. Elicitor 처리한 삼백초 추출물의 염증 억제 효과는 Figs. $5 \mathrm{~A}-\mathrm{C}$ 에서와 같이 비처리군인 대조구에 비해 우수한 염증 억제 효과를 나타내었으며, group $\mathrm{A}$ 와 group $\mathrm{B}$ 모두저농도와 고농도에서 대조구에 비해 억제율 이 큰 폭으로 상승하는 효과를 나타내었으며, 특히 고농도에서 

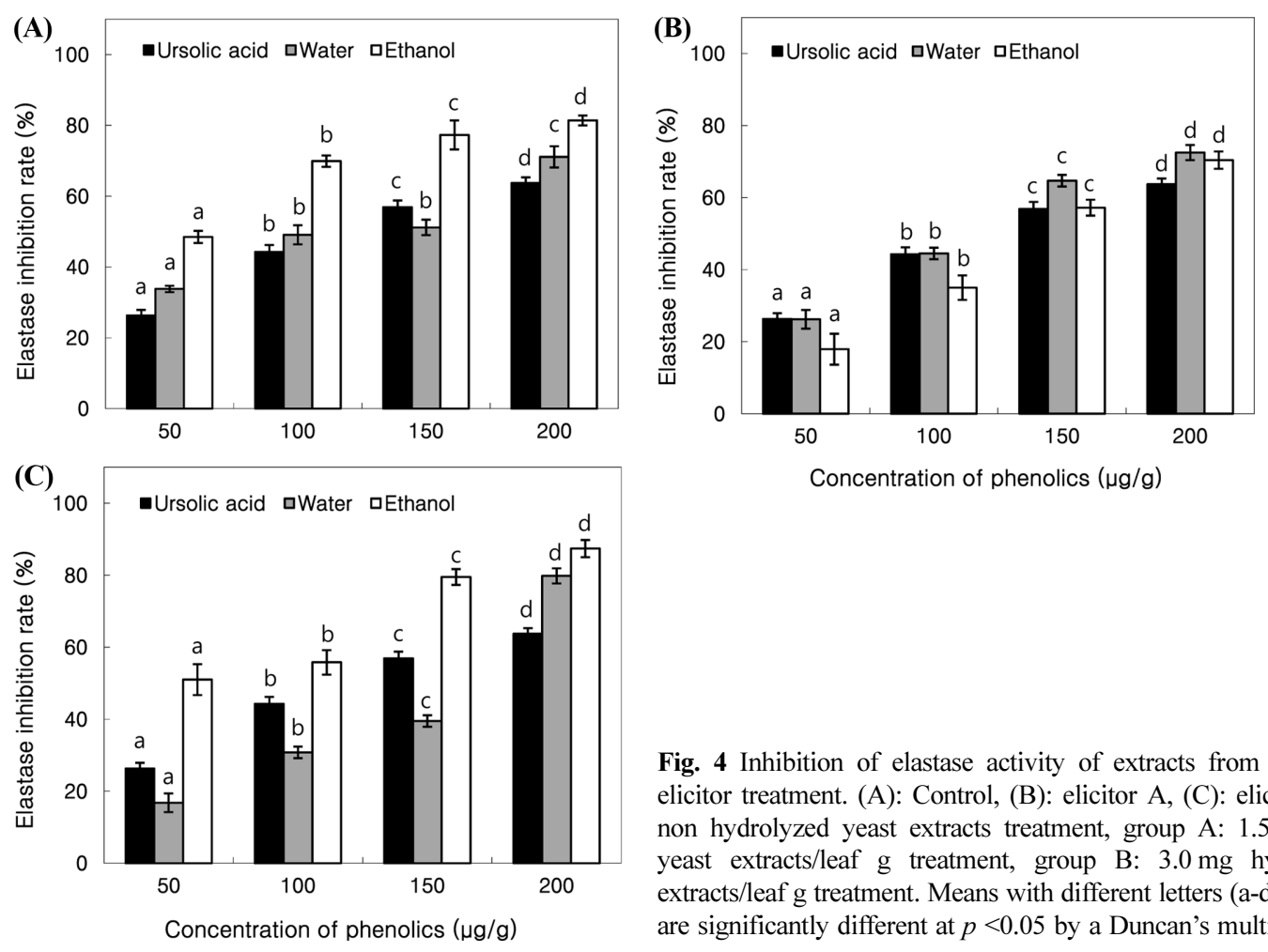

Fig. 4 Inhibition of elastase activity of extracts from $S$. chinensis by elicitor treatment. (A): Control, (B): elicitor A, (C): elicitor B. Control: non hydrolyzed yeast extracts treatment, group $\mathrm{A}: 1.5 \mathrm{mg}$ hydrolyzed yeast extracts/leaf g treatment, group B: $3.0 \mathrm{mg}$ hydrolyzed yeast extracts/leaf $g$ treatment. Means with different letters (a-d) above the bars are significantly different at $p<0.05$ by a Duncan's multiple range tests
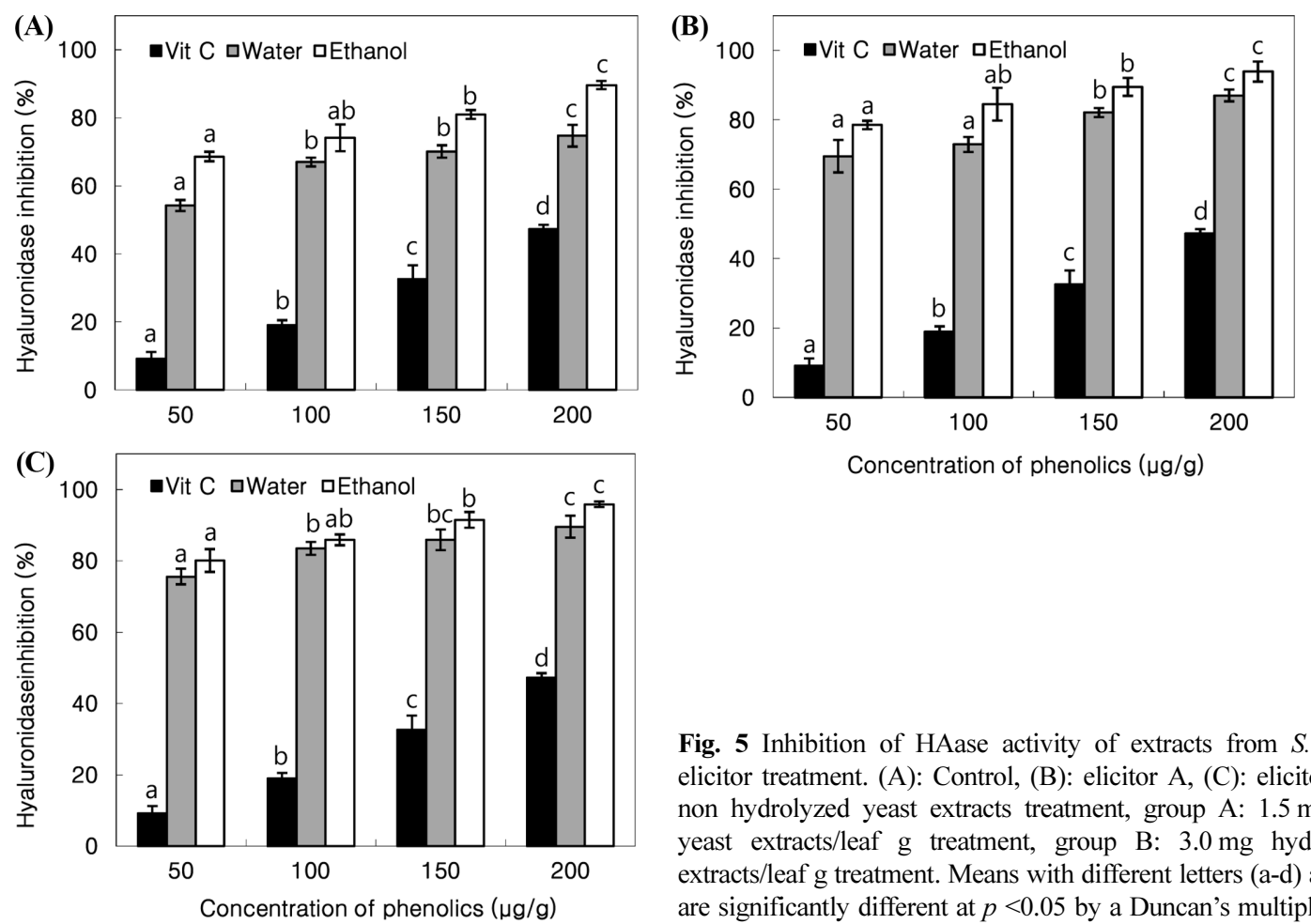

Fig. 5 Inhibition of HAase activity of extracts from S. chinensis by elicitor treatment. (A): Control, (B): elicitor A, (C): elicitor B. Control: non hydrolyzed yeast extracts treatment, group A: $1.5 \mathrm{mg}$ hydrolyzed yeast extracts/leaf g treatment, group B: $3.0 \mathrm{mg}$ hydrolyzed yeast extracts/leaf g treatment. Means with different letters (a-d) above the bars are significantly different at $p<0.05$ by a Duncan's multiple range tests

는 $100 \%$ 에 가까운 효능을 나타내어 HAase 효소에 대한 억제 율이 매우 높은 것을 확인하였다. 따라서 elicitor 처리가 유용 물질의 산업화라는 전제를 충족시키기 위한 biomass 기법으로 매우 적당하다는 것을 시사해주었다.

\section{Elicitor 처리한 삼백초 추출물의 피부상재균 억제 효과}

Elicitor 처리한 삼백초 추출물의 항균 효과는 Table 1 에서와 같 이 group A, B ethanol 추출물에서 $150 \mu \mathrm{g} / 0.1 \mathrm{~mL}$ 이상의 농 도 처리군에서 E. coli와 S. epidermidis에 대한 항균효과가 높 
Table 1 Inhibition of antimicrobial activity of extracts from $S$. chinensis by elicitor treatment

\begin{tabular}{|c|c|c|c|c|c|c|c|c|c|c|c|}
\hline \multirow{4}{*}{ Sample } & \multirow{4}{*}{ Strain } & \multicolumn{10}{|c|}{ Clear zone $(\mathrm{mm})$} \\
\hline & & \multicolumn{10}{|c|}{ Phenolic contents $(\mu \mathrm{g} / 0.1 \mathrm{~mL})$} \\
\hline & & \multicolumn{5}{|c|}{ Water extracts } & \multicolumn{5}{|c|}{$70 \%$ ethanol extracts } \\
\hline & & $0^{1)}$ & $50^{2)}$ & $100^{3)}$ & $150^{4)}$ & $200^{5)}$ & $0^{1)}$ & $50^{2)}$ & $100^{3)}$ & $150^{4)}$ & $200^{5)}$ \\
\hline \multirow{5}{*}{ Control } & P. acnes & -6) & - & - & - & - & - & - & - & - & - \\
\hline & S. aureus & - & - & - & - & - & - & - & - & - & - \\
\hline & E. coli & - & - & - & 18 & 20 & - & 12 & 13 & 18 & 21 \\
\hline & C. albicans & - & - & - & - & - & - & - & - & - & - \\
\hline & S. epidermidis & - & 11 & 11 & 16 & 21 & - & 13 & 17 & 18 & 23 \\
\hline \multirow{5}{*}{ Elicitor A } & P. acnes & - & - & - & - & - & - & - & - & - & - \\
\hline & S. aureus & - & - & - & - & - & - & - & - & - & - \\
\hline & E. coli & - & - & - & - & 14 & - & 12 & 13 & 18 & 21 \\
\hline & C. albicans & - & - & - & - & - & - & - & - & - & - \\
\hline & S. epidermidis & - & - & - & - & - & - & 11 & 15 & 17 & 23 \\
\hline \multirow{5}{*}{ Elicitor B } & P. acnes & - & - & - & - & - & - & - & - & - & - \\
\hline & S. aureus & - & - & - & - & - & - & - & - & - & - \\
\hline & E. coli & - & - & 11 & 12 & 14 & - & 11 & 15 & 19 & 21 \\
\hline & C. albicans & - & - & - & - & - & - & - & - & - & - \\
\hline & S. epidermidis & - & - & - & - & - & - & 12 & 14 & 21 & 24 \\
\hline
\end{tabular}

${ }^{10} 0 \mu \mathrm{g} / 0.1 \mathrm{~mL},{ }^{2)} 50 \mu \mathrm{g} / 0.1 \mathrm{~mL},{ }^{3)} 100 \mu \mathrm{g} / 0.1 \mathrm{~mL},{ }^{4)} 150 \mu \mathrm{g} / 0.1 \mathrm{~mL},{ }^{5)} 200 \mu \mathrm{g} / 0.1 \mathrm{~mL}$ of phenol content, ${ }^{6}$ Not detected

아지는 현상을 나타내었다. 이는 elicitor의 농도별 차이에 의해 삼백초에서 방어기작으로 만들어지는 phenolic compounds의 profile과 함량의 차이에 의한 것으로 추정이 되었다. 이상의 결 과를 종합하면, 삼백초 재배 시에 본 연구에서 사용한 elicitor 를 처리하면 수확되는 삼백초의 단위 무게당 생리활성물질인 phenolic compounds의 생산량을 높일 수 있고, 항산화 활성을 나타내는 $\mathrm{DPPH}, \mathrm{PF}$ 와 생리활성에 관여하는 효소인 elastase, HAase의 저해효과를 증가시킬 수 있는 것으로 나타났다. 또한 피부상재균에 대한 억제 효과도 증대시킬 수가 있어 산업화를 위한 원료생산에 효율적인 재배기법에 활용할 수 있을 것이라 판단되었다.

\section{초 록}

Elicitor를 처리한 삼백초의 물과 ethanol 추출물들의 기능성화장 품활성을 살펴보았다. Elicitor 처리한 삼백초 추출물의 항산화 효과는 $1.5 \mathrm{mg}$ elicitor/leaf $1 \mathrm{~g}$ (group A)에서 $3.0 \mathrm{mg}$ elicitor/ leaf $1 \mathrm{~g}$ (group B)으로 처리 농도가 높아질수록 항산화 효과는 높아지는 것으로 확인되었으며, elicitor 처리에 의해 물 추출물 보다 $70 \%$ ethanol 추출물의 항산화 효과가 더 우수한 효과를 나타내었다. Elicitor 처리한 삼백초 추출물의 미용식품활성은 elastase 억제 효과와 미백효과가 비처리군인 대조구와 유사한 효소 억제 효과를 나타내어 elicitor 처리가 삼백초 추출물의 미 백 및 주름개선 효과의 증대에는 영향을 미치지 않는 것으로 확인되었으나, 염증 억제 효과가 비처리군인 대조구에 비해 우 수한 염증 억제 효과를 나타내었으며, grpoup A와 group B 모 두에서 대조구에 비해 억제율이 큰 폭으로 상승하는 효과를 나 타내어 elicitor 처리가 유용물질의 산업화라는 전제를 충족시키
기 위한 biomass 기법으로 매우 적당하다는 것을 시사해주었다. 따라서 삼백초 재배 시에 본 연구에서 사용한 elicitor를 처리하 면 수확되는 삼백초의 단위 무게 당 생산량을 높일 수 있고, 생 리활성도 증대시킬 수가 있어 산업화를 위한 원료생산에 효율 적인 재배기법에 활용할 수 있을 것이라 판단되었다.

Keywords 건강 미용 식품 - 삼백초 - 생리활성유도제 · 추출 물 - 항균 활성

\section{References}

1. Gilchrest BA (1989) Skin aging and photoaging: an overview. J Am Acad Dermatol 21: 610-613

2. Bernstein EF, Chen YQ, Tamai K, Shepley KJ, Resnik KS, Zhang H, Tuan R, Mauviel A, Uitto J (1994) Enhanced elastin and fibrillin gene expression in chronically photodamaged skin. J Invest Dermatol 103: $182-186$

3. Scheuplein RJ, Blank IH (1971) Permeability of the skin. Physiol Rev 51(4): 702-747

4. Elias PM (1983) Epidermal lipids, barrier function, and desquamation. J Invest Dermatol 80: $44 \mathrm{~s}-49 \mathrm{~s}$

5. Blanken R, Van Vilsteren MJT, Tupker RA, Coenraads PJ (1989) Effect of min eral oil and linoleic-acid-containing emulsions on the skin vapour loss of sodium-lauryl-sulphate-induced irritant skin reactions. Contact Dermatitis 20(2): 93-97

6. Elias PM, Menon GK (1991) Structural and lipid biochemical correlates of the epidermal permeability barrier. Adv Lipid Res 24: 1-26

7. Schurer NY, Plewig G, Elias PM (1991) Stratum corneum lipid function. Dermatologica 183: 77-94

8. Soter NA (1990) Acute effects of ultraviolet radiation on the skin. Semin Dermatol 9(1): 11-15

9. Lee EH, Kim BO, Cho YJ (2017) Inhibitory activities on biological 
enzymes of extracts from Oplismenus undulatifolius. J Appl Biol Chem 60(2): 101108

10. Lee JE, Lee EH, Kim BO, Cho YJ (2017) Biological activities of extracts from Caryopteris incana Miq. J Appl Biol Chem 60(1): 61-68

11. Kohno Y, Takahashi M (1995) Peroxidation in human skin and its prevention. JOCS 44: 248-255

12. Mukhtar H, Elmets CA (1996) Photocarcinogenesis: mechanisms, models and human health implications. Photochem Photobiol 63(4): 356-357

13. Chiba K, Kawakami K, Sone T, Onoue M (2003) Characteristics of skin wrinkling and dermal changes induced by repeated application of squalene monohydroperoxide to hairless mouse skin. Skin Pharmacol Appl Skin Physiol 16: 242-251

14. Mauviel A, Halcin C, Vasiloudes P, Parks WC, Kurkinen M, Uitto J (1994) Uncoordinate regulation of collagenase, stromelysin, and tissue inhibitor of metalloproteinases genes by prostaglandin $\mathrm{E}_{2}$ : Selective enhancement of collagenase gene expression in human dermal fibroblasts in culture. J cell Biochem 54: 465-472

15. Pentland AP, Shapiro SD, Welgus HG (1995) Agonist-induced expression of tissue inhibitor of metalloproteinases and metalloproteinases by human macrophages is regulated by endogenous prostaglandin $\mathrm{E}_{2}$ synthesis. J Invest Dermatol 104: 52-57

16. Park SK, Kim SN, Lee JC, Kim HS, Kim YJ, Lee BG, Chang IS (2004) Anti-aging effect on skin with Jaeum-Dan (JED). Kor J Herbology 19: 67-76

17. Kwak JW, Kwon CH (1988) Pharmacological studies on Saururus chinensis baill. Bull KH Pharma Sci 16: 137-154

18. Cho YJ, Park SY, Kim KB (2014) Preparing methods of Saururus chinensis increased inhibitory compounds against gastritis using hydrolyzed yeast with enzyme. Patent101,469,901, 1 Dec 2014

19. Andarwulan N, Shetty K (1999) Phenolic content in differentiated tissue cultures of untransformed and Agrobacterium-transformed roots of anise (Pimpinella anisum L.). J Agric Food Chem 47: 1776-1780

20. Vincent J, Hearing JR (1987) Mammalian monophenol monooxygenase (tyrosinase): purification, properties, and reactions catalyzed. Method Enzymol 142: 154-165

21. Wunsch E, Heidrich HG (1963) Zur quantitativen bestimmung der kollagenase. Hoppe-Seyler's Z Physiol chem 333: 149-151

22. Kraunsoe JA, Claridge TD, Lowe G (1996) Inhibition of human leukocyte and porcine pancreatic elastase by homologues of bovine pancreatic trypsin inhibitor. Biochemistry 35: 9090-9096

23. Lee JT, Jeong YS, An BJ (2002) Physiological activity of Salicornia herbacea and its application for cosmetic materials. Kor J Herbology 17: 51-60

24. Davidson PM, Parish ME (1989) Methods for testing the efficacy of food antimicrobials. J Food Technol 43: 148-155

25. Giacomoni PU, Rein G (2001) Factors of skin ageing share common mechanism. Biogerontology 2: 219-229

26. Cannell RJ, Kellam SJ, Owsianka AM, Walker JM (1988) Results of a large scale screen of microalgae for the production of protease inhibitors. Planta Med 54(1): 10-14 